Cybernetics: Journal Educational Research and Social Studies

Volume 2, Nomor 4, Oktober 2021

Journal Homepage: http://pusdikra-publishing.com/index.php/jrss

\title{
Nilai Karakter Dalam Penerapan Tradisi Pantun Kebudayaan Suku Melayu Deli Dusun 17 Desa Bandar Khalifah
}

\author{
Wawan Akbar
}

Universitas Negeri Medan

Corresponding Author : $\otimes$ wawanakbar05@gmail.com

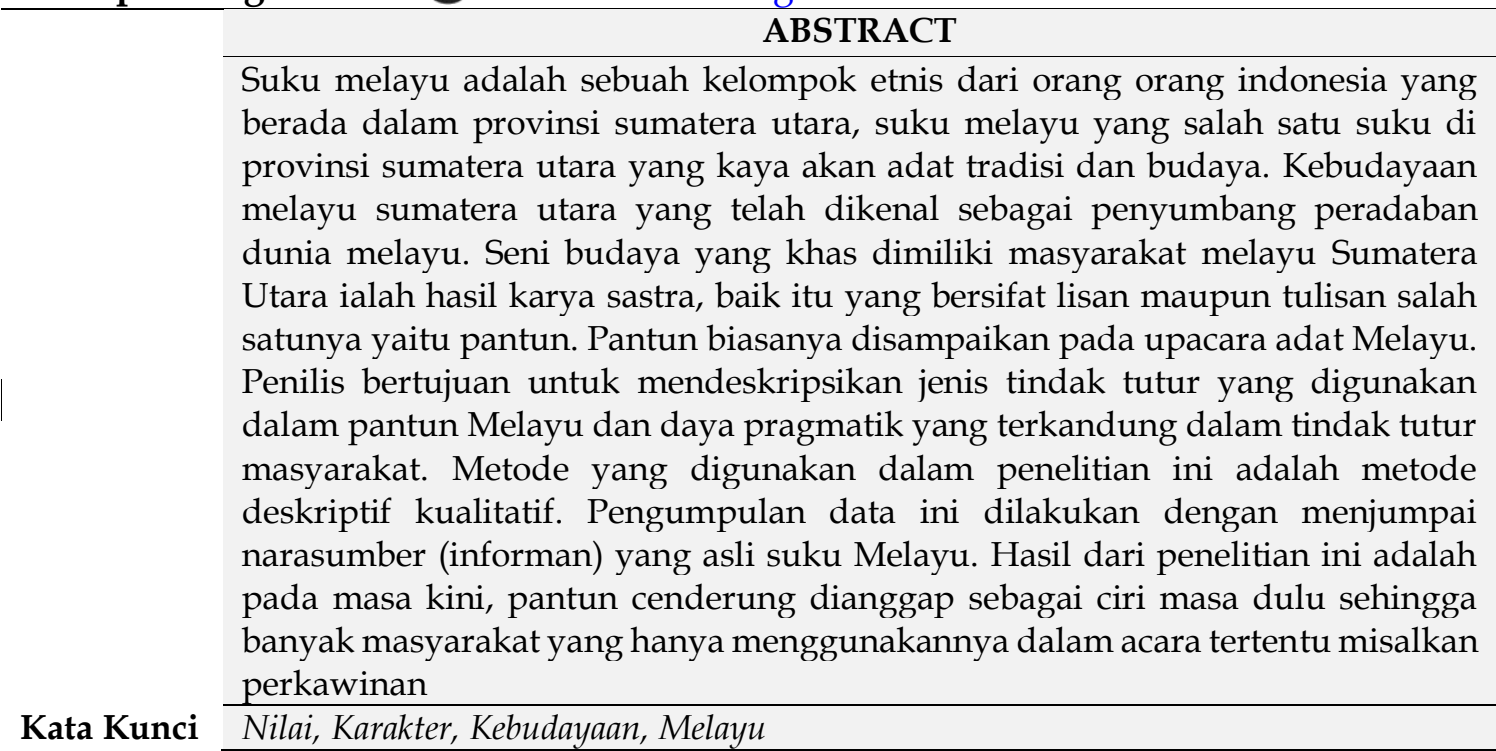

\section{PENDAHULUAN}

Nilai yaitu dapat diartikan sifat atau hal-hal yang penting dan berguna bagi kehidupan manusia. Nilai adalah sesuatu yang berhubungan dengan kognitif dan afektif (Najib, 2015 : 47). Nilai juga dapat dikatakan sebagai suatu norma atau sebuah standar yang sudah ditentukan dan diyakini secara psikologis telah menyatu dalam diri individu. Di dalam nilai nilai terdapat pembakuan mengenai sesuatu yang dinilai baik dan buruk serta pengaturan perilaku (Abdul Majid, 2015 : 23). Selain itu nilai dapat diartikan sebagai norma-norma yang dianggap baik oleh setiap individu, hal inilah yang selanjutnya akan akan menuntun setiap individu menjalankan tugas-tugasnya seperti nilai kejujuran, nilai kesederhanaan dan lain sebagainya (Sanjaya, dalam Noor Yanti 2016 : 2). Sedangkan karakter dapat dikatakan sebagai cerminan dari kepribadian seseorang cara berpikir sikap dan perilaku (Barnawi 2012 : 20). Selain itu nilai karakter dapat dikatakan sebagai suatu ide atau konsep yang dijadikan sebagai pedoman atau patokan dalam berperilaku bagi seseorang (Solichin, 2015 : 47).

Bahasa ialah sebuah kunci yang utama sanagat penting dalam kehidupan masyarakat, bahasa yang digunakan manusia sebagai alat komunikasi dengan 
sekitar nya adalah melalui yaitu sebuah tuturan. Tuturan yang dimaksud dapat diekspresikan melalui media massa baik lisan maupun tulisan. Masyarakat pengguna bahasa dalam situasi tertentu dan untuk mencapai tujuan tertentu akan selalu berusaha memilih dan menggunakan kaidah-kaidah tuturan yang sesuai dengan peraturan. Kepemilikan kita lawan tutur, sedangkan lawan tutur menerima informasi tersebut. Oleh karena itu, apa yang ada dalam pikiran penutur tersampaikan, maka komunikasi dapat dikatakan berhasil. Proses perubahan pembicaraan terjadi begitu cepat, terasa sebagai suatu peristiwa biasa dan wajar sehingga komunikasi berjalan dengan lancar. Tindak tutur dapat terjadi dalam semua komunikasi linguistik. Dalam hal ini, manusia tidak hanya sekedar mengerti apa yang telah diujarkan oleh si penutur, tetapi juga konteks yang digunakan dalam ujaran tersebut. Kegiatan semacam ini berkaitan dengan tindak tutur, yaitu tuturan yang disertai dengan gerak, sikap anggota badan maupun ekspresi tertentu.

Pengertian tindak tutur itu sendiri adalah hasil dari suatu kalimat dalam kondisi tertentu dan merupakan satuan terkecil dari komunikasi bahasa. Menurut Searle (Wijana, 2009), tindak tutur secara pragmatis dapat diklasifikasikan menjadi tiga jenis tindak tutur. Ketiga tindak tutur tersebut terdiri dari tindak tutur lokusi (locutionary acts), tindak tutur ilokusi (illocutionary acts), dan tindak tutur perlokusi (perlocutionary acts). Tuturan ekspresif merupakan bagian dari tindak tutur ilokusi. Tututuran ekspresif adalah tindak tutur yang dimaksudkan penuturnya agar ujaran tersebut dapat diartikan sebagai evaluasi tentang hal yang disebutkan dalam tuturan itu dan memiliki beberapa fungsi di dalamnya. Tuturan ekspresif memiliki beberapa fungsi yang terdiri dari mengkritik / menyindir, mengeluh, menyalahkan, mengucapkan selamat, mengucapkan terima kasih, menyanjung dan meminta maaf. Sebagai contoh pantun melayu selalu diutamakan "budi" dan "bahasa" yang menunjukkan sopan santun dan tingginya peradaban.

\section{Nilai Karakter}

Nilai dapat diartikan sebagai sifat atau hal-hal yang penting dan berguna bagi kehidupan manusia. Nilai adalah sesuatu yang berkaitan dengan kognitif dan afektif (Najib, 2015 : 47). Nilai juga dapat dikatakan sebagai suatu norma atau sebuah standar yang sudah ditentukan dan diyakini secara psikologis telah menyatu dalam diri individu. Di dalam nilai-nilai terdapat pembakuan mengenai sesuatu yang dinilai baik dan buruk serta pengaturan perilaku (Abdul Majid, 2015 : 23).

Selain itu nilai (value) dapat diartikan sebagai norma-norma yang dianggap baik oleh setiap individu, hal inilah yang selanjutnya akan menuntun setiap individu menjalankan tugas-tugasnya seperti nilai kejujuran, nilai 
kesederhanaan dan lain sebagainya (Sanjaya, dalam Noor Yanti 2016 : 2). Sedangkan karakter dapat dikatakan sebagai cerminan dari kepribadian seseorang; cara berpikir, sikap dan perilaku (Barnawi 2012 : 20). Selain itu nilai karakter dapat dikatakan sebagai suatu ide atau konsep yang dijadikan sebagai pedoman atau patokan dalam berperilaku bagi seseorang (Solichin, $2015: 47$ ).

\section{Kebudayaan}

Menurut ilmu antropologi "kebudayaan" adalah keseluruhan sistem gagasan, tindakan dan hasil karya manusia dalam kehidupan masyarakat yang dijadikan milik diri manusia dengan belajar (Koentjaraningrat, 2009: 153). Hal tersebut berarti bahwa hampir semua tindakan manusia itu adalah "kebudayaan" karena hanya sedikit kegiatan manusia yang tanpa belajar, hal itu disebut tindakan naluri, refleks, dan sebagainya. Kemampuan manusia dapat mengembangkan konsep-konsep yang ada dalam kebudayaan. Sebagai contoh dahulu makan dengan tangan sekarang semakin maju dan orang bisa membuat alat yaitu sendok sehingga dapat mengubah kehidupan seseorang menjadi lebih bersih.

Selain itu juga ada nilai budaya yang terkandung dalam kebudayaan. Nilai budaya adalah tingkat yang paling tinggi dan paling abstrak dari adat-istiadat. Nilai budaya berfungsi juga sebagai pedoman hidup manusia dalam masyarakat, tetapi sebagai konsep, suatu nilai budaya itu bersifat sangat umum, mempunyai ruang lingkup yang sangat luas, dan biasanya sulit diterangkan secara rasional dan nyata. Namun, justru karena sifatnya yang umum, luas, dan tidak konkret, maka nilai-nilai budaya dalam suatu kebudayaan berada dalam daerah emosional dari alam jiwa para individu yang menjadi warga dan kebudayaan yang bersangkutan (Koentjaraningrat, 2009: 153).

\section{METODE PENELITIAN}

Dalam penelitian ini, penulis menggunakan metode deskriptif kualitatif dengan menggunakan pendekatan studi kasus. Sumber data dikumpulkan dari beberapa narasumber berupa catatan rekaman dan dokumentasi yang diadakan dalam acara pernikahan sesuai suku Melayu di dusun 17 desa bandar khalifah. Sedangkan dalam menurut djunaidi (2014:25), penelitian kualitatif ialah penelitian yang menghasilkan penemuan-penemuan yang tidak dapat dicapai dengan menggunakan prosedur statistik atau dengan cara-cara kuantifikasi. Penelitian kualitatif dapat menunjukan kehidupan masyarakat, sejarah, tingkah laku, fungsionalisasi organisasi, pergerakan nasional, dan hubungan kekerabatan. Hubungan kualitatif ini mengacu pada proses pelaksanaan dilapangan, bisa dilaksanakan dengan opservasi langsung, opservasi partisipan, wawacara mendalam, dokumen-dokumen, foto-foto maupun rekaman suara 
Cybernetics: Journal of Research and Educational Studies

Volume 2 Nomor 4, Oktober 2021

Halaman 48-53

dan data lain yang dapat menunjang keberlangsungan dalam penelitian ini supaya mendapatkan data yang valid

\section{HASIL DAN PEMBAHASAN}

Pantun merupakan bentuk puisi dalam kesusastraan Melayu yang paling luas dikenal di masyarakat. Kata pantun mempunyai asal-usul yang cukup panjang dengan persamaan dari bahasa Jawa yaitu kata parik yang berarti pari, artinya paribasa atau peribahasa dalam bahasa Melayu. Pada masa lalu pantun digunakan oleh masyarakat untuk melengkapi pembicaraan sehari-hari. Sekarang pun sebagian besar masyarakat Melayu masih menggunakannya. Pantun dipakai oleh para pemuka adat dan tokoh masyarakat dalam pidato, oleh para pedagang yang menjajakan dagangannya, orang yang ditimpa kemalangan, orang yang ingin menyatakan kebahagiaannya. Oleh karena itu, walaupun pantun masih sering dibacakan oleh orang-orang Melayu, khususnya di daerahdaerah pedesaan, dalam berbagai upacara adat, pidato resmi pemerintah, pementasan budaya, dan kegiatan-kegiatan keseharian lainnya, tetapi pembacaan pantun hanyalah sebagai prasyarat (pelengkap) acara bukan sebuah proses pewarisan nilai-nilai. Pantun merupakan khazanah lisan Melayu tradisional yang terdiri dari empat baris yang mandiri dengan skema rima abab. Dua baris pertama merupakan pembayang atau sampiran, sedangkan dua baris berikutnya mengandungi isi.

Pengaruh pantun dalam masyarakat Melayu sangat luas karena dijadikan sebagai alat berkomunikasi dalam adat istiadat Melayu untuk menyampaikan isi hati dan hajat seperti sanjungan, pemujaan dan melahirkan penghargaan dan ucapan terima kasih kepada seseorang dalam sesuatu keadaan. Selain itu, pantun juga dianggap sebagai alat hiburan, alat pendidikan dan alat menguji ketajaman akal dan kehalusan perasaan serta sebagai alat untuk mendapatkan gambaran masyarakat. Pantun Melayu juga dapat membentuk serta membina nilai-nilai murni dalam diri seseorang karena di dalamnya terkandung makna-makna tersirat dan dapat dijadikan pedoman. Fungsi pantun Melayu adalah sebagai wadah untuk meluahkan perasaan kasih sayang dalam kalangan masyarakat Melayu tanpa batasan umur. Pantun akan dihiasi dengan kata-kata yang indah, berbunga-bunga, puji-pujian yang menggambarkan perasaan kasih, sayang, cinta dan rindu yang mendalam.

Pantun digunakan oleh masyarakat Melayu dalam acara adat seperti merisik, meminang (melamar) dan dalam pernikahan adat Melayu. Pantun ini disampaikan oleh para pemangku adat, tidak hanya merupakan retorika khas dalam rangkaian sebuah prosesi, tetapi juga menjadi media untuk merawat ingatan komunitas pada leluhur, alam, nilai, norma, dan hukum serta aturan- 
Cybernetics: Journal of Research and Educational Studies

Volume 2 Nomor 4, Oktober 2021

Halaman 48-53

aturan adat itu sendiri. Tindak tutur dalam penyampaian pantun ini bergantung pada siapa, kapan dan dimana tuturan tersebut dilakukan, sehingga tuturan ini tidak mudah diidentifikasikan begitu saja. Hal ini karena pantun menjadi wadah yang digunakan untuk menyampaikan dan menjelaskan sesuatu yang penting kepada masyarakat dan mudah dipahami oleh masyarakat tradisional Melayu. Melihat perkembangan pantun dari zaman ke zaman, posisi pantun yang tetap kuat dari masa ke masa sehingga buku-buku pantun masih diterbitkan yang didalam penciptaan pantun secara tertulis, namun, sebagian besar buku-buku itu bukanlah pantunpantun karya individu (seperti kumpulan pantun Haji Ibrahim), melainkan hasil pengumpulan pantun-pantun yang terserak dalam berbagai tradisi lisan warisan. Penciptaan pantun secara tertulis didalamnya mencerminkan kebudayaan berkaum dan berbangsa.

Dalam penelitian ini melihat nilai karakter yang terkandung dalam budaya turut berpantun ini sangatlah baik, dikarenakan dalam turut berpantun yang biasa nya digunakan dalam tradisi suatu pernikahan ini menjadi suatu sikap saling menghargai antara kedua keluarga pasangan, lebih membuat suasana pernikahan itu menjadi lebih terasa kekeluargaan nya, dalam penelitian di dusun 17 desa bandar khalifah, yang peneliti telah lakukan masih terlaksana budaya turut berpantun yang dilakukan suku melayu dalam pernikahan, dengan menggunakan pagar terlebih dahulu sambil menunggu keluarga pasangan datang untuk melaksanakan resepsi pernikahan dan menjadi hiburan bagi masyarakat yang melihat dan mendengarnya. Oleh sebab itu budaya yang terdapat dalam suku melayu khusus nya didesa bandar khalifah yang menjadi penelitian penulis harus tetap terjaga dengan baik, dan menjadi nilai karakter untuk setiap masyarakat, karena hasil dari terlaksananya budaya turut berpantun ini menjadikan seni yang sangat baik diterapkan dan pembelajaran dalam sastra khusunya untuk lebih lagi mengembangkan kata pujian untuk pasangan yang melaksanakan resepsi pernikahan.

\section{KESIMPULAN}

Berdasarkan hasil penelitian diperoleh kesimpulan didalam kebudayaan melayu mendapat peran strategis dalam konteks Sumatera Utara. Budaya melayu di Sumatera Utara yang telah dikenal sebagai penyumbang peradaban Dunia Melayu. Nilai karakter dalam seni budaya melayu turut berpantun ini menjadi khas dimiliki masyarakat melayu sumatera utara adalah hasil karya sastra, baik itu yang bersifat lisan maupun tulisan salah satunya yaitu pantun. Pantun biasanya disampaikan pada upacara adat melayu dan bertujuan untuk mendeskripsikan jenis tindak tutur yang digunakan dalam pantun melayu dan daya pragmatik yang terkandung dalam tindak tutur masyarakat. 
Cybernetics: Journal of Research and Educational Studies

Volume 2 Nomor 4, Oktober 2021

Halaman 48-53

\section{DAFTAR PUSTAKA}

Istrani, 2012. Kurikulum Sekolah Berkarakter . Medan : Media Persada.

Amran, Halim, 1981. Fungsi Politik Bahasa Nasional. Dalam Politik Bahasa Nasional. Jakarta: Balai Pustaka.

Mahsun, M. S. 2010. Genolinguistik: Kolaborasi Linguistik dengan Genetika dalam Pengelompokan Bahasa dan Populas Penuturnya. Yogyakarta: Pustaka Pelajar.

Rahardi, Kunjana. 2003. Berkenalan dengan Ilmu Bahasa Pragramatik. Malang: Dioma. Searle. 1969. Speech Acts An Essay in The Philosophy of Language. Oxford: Basil Blacwell.

Sinar, Luckman, S., B. 2005. Adat Budaya Melayu Jati Diri Dan Kepribadian. Sumatera Utara: Forkala. Suyono. 1990. Pragmatik: Dasar - Dasar dan Pengajaran. Malang: YA3.

Thosim. 2002. Kumpulan Peribahasa Pantun. Surabaya: Cahaya Agency.

Wijana, I Dewa Putu. 1996. Dasar - Dasar Pragmatik. Yogyakarta: Duta Wacana University Press.

Bima Prama Citra, Zainab MZ 2019. Tindak Tutur Pantun Melayu Deli. Jurnal Penelitian Pendidikan Bahasa dan Sastra. 